\title{
МОРФОЛОГІЧНІ ЗМІНИ ПРИ ЕКСПЕРИМЕНТАЛЬНОМУ ЛІКУВАННІ ЦУКРОВОГО ДІАБЕТУ 2 ТИПУ СОЛЯМИ ГУМІНОВИХ КИСЛОТ.
}

\author{
Ковальчук Олена ${ }^{1}$, Педоренко Катерина ${ }^{2,}$ Ковальчук Світлана ${ }^{3}$ \\ ${ }^{1}$ Студент медичного факультету №1, ВНМУ ім. М.І. Пирогова \\ 2Лікар-патологоанатом, КНП «ВОПАБ ВОР» м. Вінниці \\ ${ }^{3}$ Вчитель хімії, вчитель методист, ліцей №25 м. Житомира
}

\begin{abstract}
Анотація. Захворюваність на иукровий діабет невпинно зростає набуваючи характеру справжньої епідемії та стає викликом не тільки для медицини, але й суспільства вцілому. Зважсаючи на те, щзо близько 90\% усіх хворих припадає на хворих з иукровим діабетом 2 типу. Пріоритетним напрямком серед дослідників є пошук нових методів лікування иукрового діабеmу 2 типу. Існує ряд статей про лікування иукрового діабету 2 типу солями гумінових кислот. Дана стаття висвітлює проведене експериментальне дослідження лікувальних властивостей солей гуматів на шурах. Отримані дані під час дослідження та після дослідження морфологічних змін органів-міменей (печінка, нирки міокард) свідчать про недостатню терапевтичну дію солей гумінових кислот.
\end{abstract}

Ключові слова: гумат, гумат натрію, морфологічне дослідження, солі гумінових кислот, цукровий діабет 2 типу, терапевтична дія гумінових кислот.

Вступ. Цукровий діабет (ЦД) - мультифакторіальне захворювання, що протягом останнього десятиліття стало тягарем не тільки для системи охорони здоров'я, а й суспільства вцілому. Згідно з останніми даними, у 2030 році кількість хворих на ЦД сягне 552 млн (WHO. Diabets,2020). У 2019 році лише у США було витрачено понад 327,8 мільярдів доларів на боротьбу з пандемією XXI століття. Більшість витрат, а саме $80 \%$ від загальної суми, припадають на обстеження та лікування хворих з ускладненнями (Roglic,2016), саме тому приорітетним напрямком залишається пошук ліків для найкращого контролю глікемічного профілю хворих. Увагу до себе привертає дослідження гуматів та їх похідних. Існує безліч досліджень, у яких описується дезінтокаційна, протизапальна, антибактеріальна та антиоксидантна здатністі солей гуматів. (van Rensburg \& Naude, 2009; Aeschbacher, Sander \& Schwarzenbach, 2010; Аввакумова, Герчиков, Хайруллина \& Жданова, 2011). У деяких роботах згадується цукрознижуююча та протекторна здатності солей гуматів (Левинский, $2000)$, тому виходячи $з$ того, що пусковим ме- ханізмом розвитку ЦД 2 типу є збільшення рівня глюкози крові, вважаємо за потрібне дослідити новий препарат для корекції глікемії та протекції органної структури.

Зважаючи на наші попередні дослідження, найбільших структурних змін при дії гіперглікемії зазнає печінка, нирки та міокард, вважаємо за потрібне дослідити морфологічні зміни у цих органах при використанні експериментального лікування.

Методи: Для дослідження було використано 40 щурів, розділених на 5 експериментальних груп. 1 група - щурі для підтвердження моделювання дексаметазонового ЦД 2 типу, 2 група - щурі, яким 14 днів моделювався ЦД 2 типу та протягом 7 днів застосовувалось експериментальне лікування гуматом, 3 група щурі, яким 14 днів моделювався ЦД 2 типу та 14 днів застосовувалось експериментальне лікування, 4 група - щурі, яким 21 день моделювався ЦД 2 типу та 7 днів застосовувалось експериментальне лікування, 5 група - щурі, яким 28 днів моделювався ЦД 2 типу та протягом 7 днів застосовувалось експериментальне лікування гуматом (таб. 1). Моделювання екс- 
Таб. 1. Групи, на які були розділені щурі з відповідною схемою моделювання

\begin{tabular}{|c|l|}
\hline Група № & \multicolumn{1}{|c|}{ Дослідження } \\
\hline 1 & щурі для підтвердження моделювання дексаметазонового ЦД 2 типу \\
\hline 2 & $\begin{array}{l}\text { щурі, яким } 14 \text { днів моделювався ЦД } 2 \text { типу та протягом } 7 \text { днів застосовувалось } \\
\text { експериментальне лікування гуматом }\end{array}$ \\
\hline 3 & $\begin{array}{l}\text { щурі, яким } 14 \text { днів моделювався ЦД } 2 \text { типу та } 14 \text { днів застосовувалось експериментальне } \\
\text { лікування }\end{array}$ \\
\hline 4 & $\begin{array}{l}\text { щурі, яким } 21 \text { день моделювався ЦД } 2 \text { типу та } 7 \text { днів застосовувалось експериментальне } \\
\text { лікування }\end{array}$ \\
\hline 5 & $\begin{array}{l}\text { щурі, яким 28 днів моделювався ЦД } 2 \text { типу та протягом } 7 \text { днів застосовувалось } \\
\text { експериментальне лікування гуматом }\end{array}$ \\
\hline
\end{tabular}

периментального цукрового діабету у щурів відбувалось за експериментальною моделлю за патентом Месової А.М.: Способ воспроизведения сахарного диабета 2 типа у молодых крыс//(19)KZ(13)AU(11)22018. Експериментальне лікування проводилось гуматом натрію з розрахунку 10 мг/кг маси тіла, щоденно протягом терміну визначеного для кожної групи. Забій тварин проводився після завершення експериментального лікування. Для проведення патоморфологічного дослідження тканини фіксувались в 10\% забуферному розчині формаліну, проводився забір найбільш змінених ділянок, зневоднювали в спиртах, просочували парафінами і заливали в парафінові блоки. Після приготування зрізів на мікротомі, проводилось фарбування гематоксилін-еозином, за Ван-Гізоном, Суданом III та ШИК-реакцією. Мікроперпарати досліджувались на морфометричному комплексі Olympus imaging CORP Model NoE-410DC7:4VD56547931 зі збільшенням 40, 100, 200, 400,800.

При дослідженні мікропрепаратів печінки у щурів 1 групи спостерігались крововиливи в паренхіму органу, зміни в структурі гепатоцитів, а саме дрібно та великокрапельна жирова дистрофія, лімфогістоцитарна інфільтрація. Синусоїди розширені. Збільшення кровонаповнення вен. Вогнищеві зміни судинної стінки, іiі потовщення та розшарування. У щурів 2 групи в паренхімі печінки - крововиливи, тотальна зерниста дистрофія, вогнищева вакуольна жирова дистрофія гепатоцитів та їх лімфогістоцитарна інфільтрація. У піддослідних тварин 3 групи спостерігалась масивна дистрофія гепатоцитів їх лімфогістоцитарна інфільтрація, балонна дистрофія. Потовщення та розшарування судинної стінки. У 4 групі дослідження виявлена масивна жирова дистрофія гепатоцитів, утворення перевазатів. Потовщення та розшарування судинної стінки, в просвіті - сладж феномен. У мікроперпаратах печінки щурів 5 групи відмічається дифузна важка жирова дистрофія гепатоцитів. Переповнення судин, вогнищево - стоншеня та стовщення судинної стінки (рис.1).

При мікроскопічному дослідженні нирок щурів 1 групи виявлений стаз в приносних артеріолах. Повнокрів'я судин. У ниркових канальцях спостерігається ущільнення, вогнищева деструкція епітелію. Незначні явища запалення. Наявне відкладання білкових депозитів в просвіті канальців, виражена дистрофія епітелію канальців аж до розвитку вогнищевого некрозу. Незначне потовщення стінки капілярів. У щурів 2 групи виявлена дистрофія канальців, крововиливи та деформація клубочків. В усіх судинах нирки - стовщення судинної стінки. У досліджених мікропрепаратах нирок щурів 3 групи спостерігався розвиток дистрофії середнього ступеня важкості. Повнокрів'я усіх судин, стази. У клубочках - крововиливи, деформації клубочків, нерівномірне їх кровонаповнення. Дистрофія канальців. У піддослідних тварин 4 групи виявлено нерівномірне потовщення стінок судин, їх розшарування. В клубочках - крововиливи, їх деформація та зменшення кровонаповнення. Дистрофія клубочків середнього ступеня важкості. У мікропрепаратах нирок щурів 5 групи відмічається початок вогнищевого розвитку «щитоподібної нирки», масивні крововиливи в клубочки та їх масивна важка дистрофія (рис.2).

При дослідженні серця щурів у 1 групі макроскопічно - незначне розростання жирової тканини зі сторони парієтальної частини 

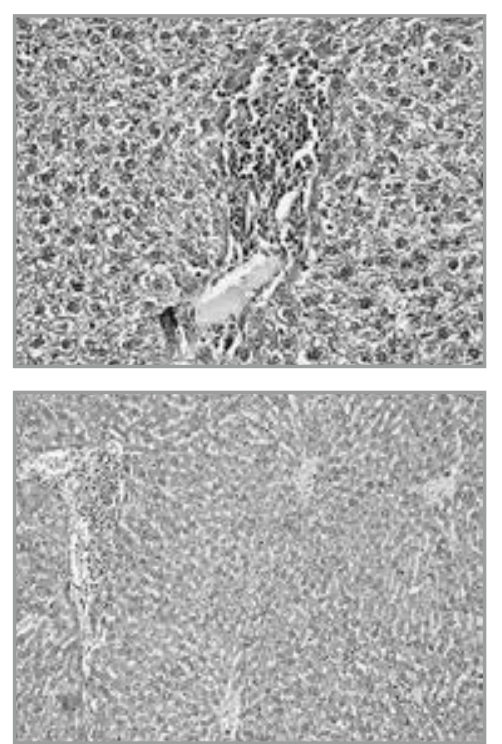

$\mathrm{X} 400$

гематоксилін-

еозин 1 група

X200

гематоксилін-

еозин 2 група
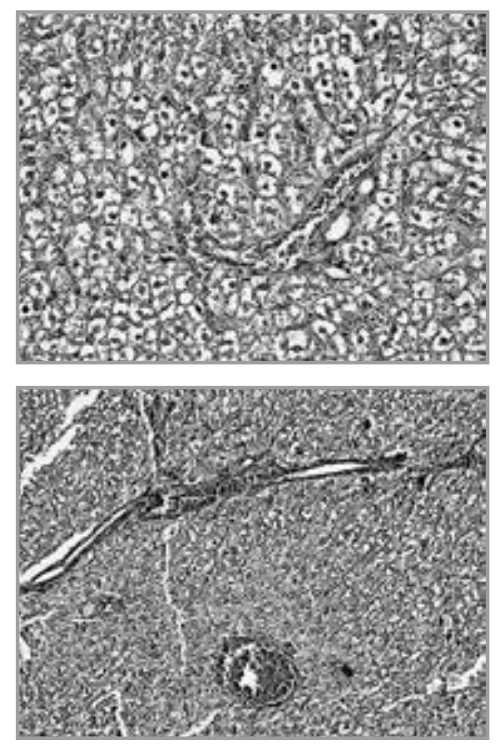

$\mathrm{X} 400$

гематоксилінеозин 3 група

X200

гематоксилінеозин 4 група

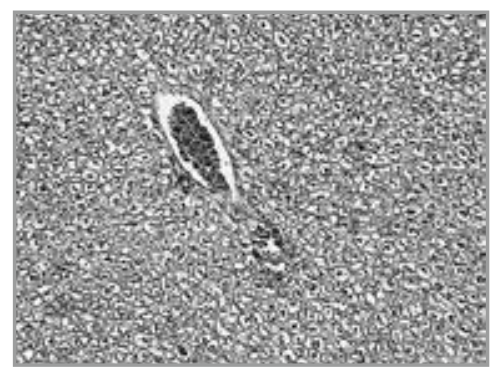

$\mathrm{X} 400$

гематоксилінеозин 5 група

Pис.1.

Дослідження мікропрепаратів печінки відповідно до експериментальної групи

перикарду; мікроскопічно - виявлена дистрофія, вогнищева дефрагментація кардіоміофібрил, втрата просмугованості. Відбувається незначне пропотівання елементами плазми. Некробіотичні зміни, що нагадують асептичний некроз. Судини дилатовані. $\mathrm{У}$ мік-

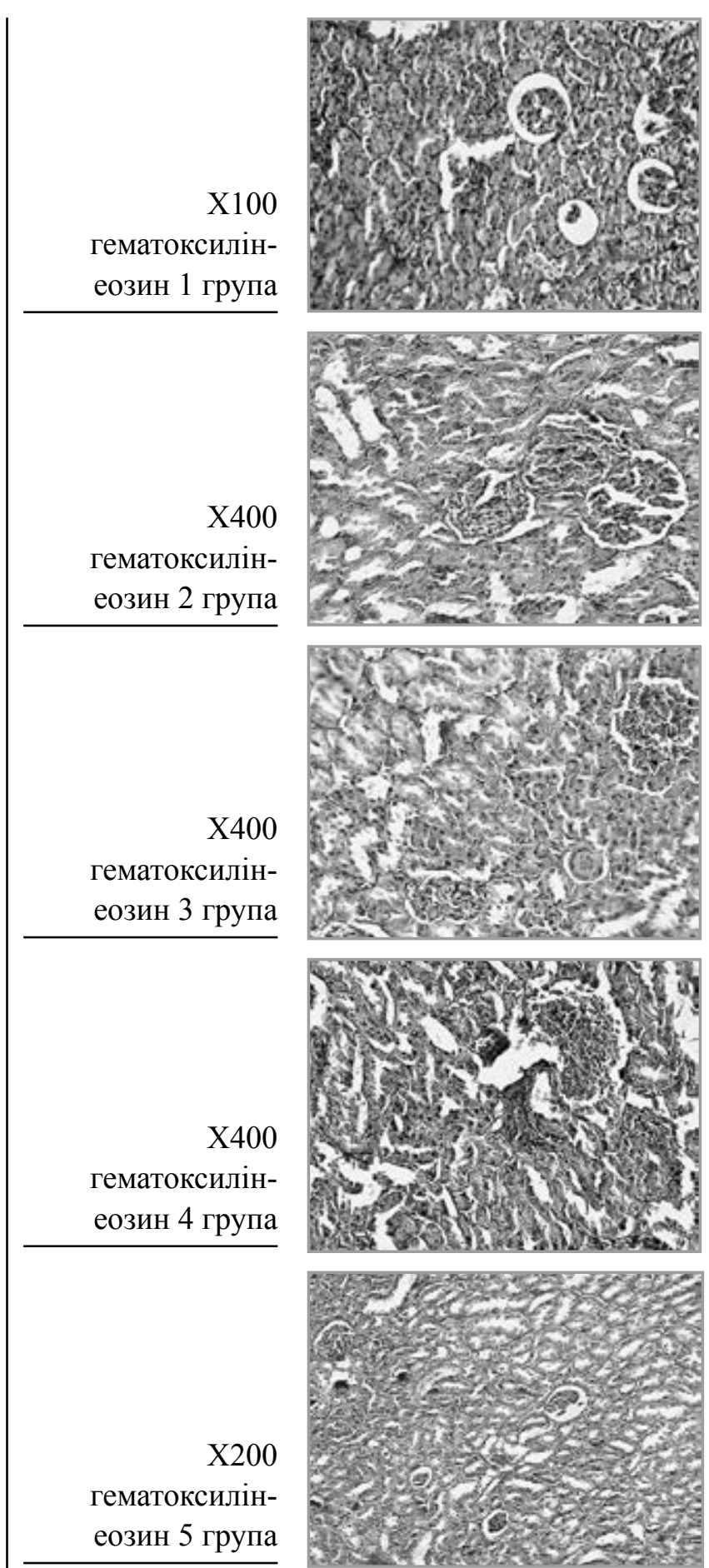

\section{Рис.2.}

Дослідження мікропрепаратів нирок щурів відповідно до експериментальної групи

ропрепаратах серцевого м'яза щурів 2 групи спостерігалась втрата просмугованості, крововиливи, утворення перевазатів, виражена дистрофія кардіоміофібрил. Зміни тканини нагадують перед некротичні. Судини розширені. Виражена дистрофія кардіоміофібрил, 

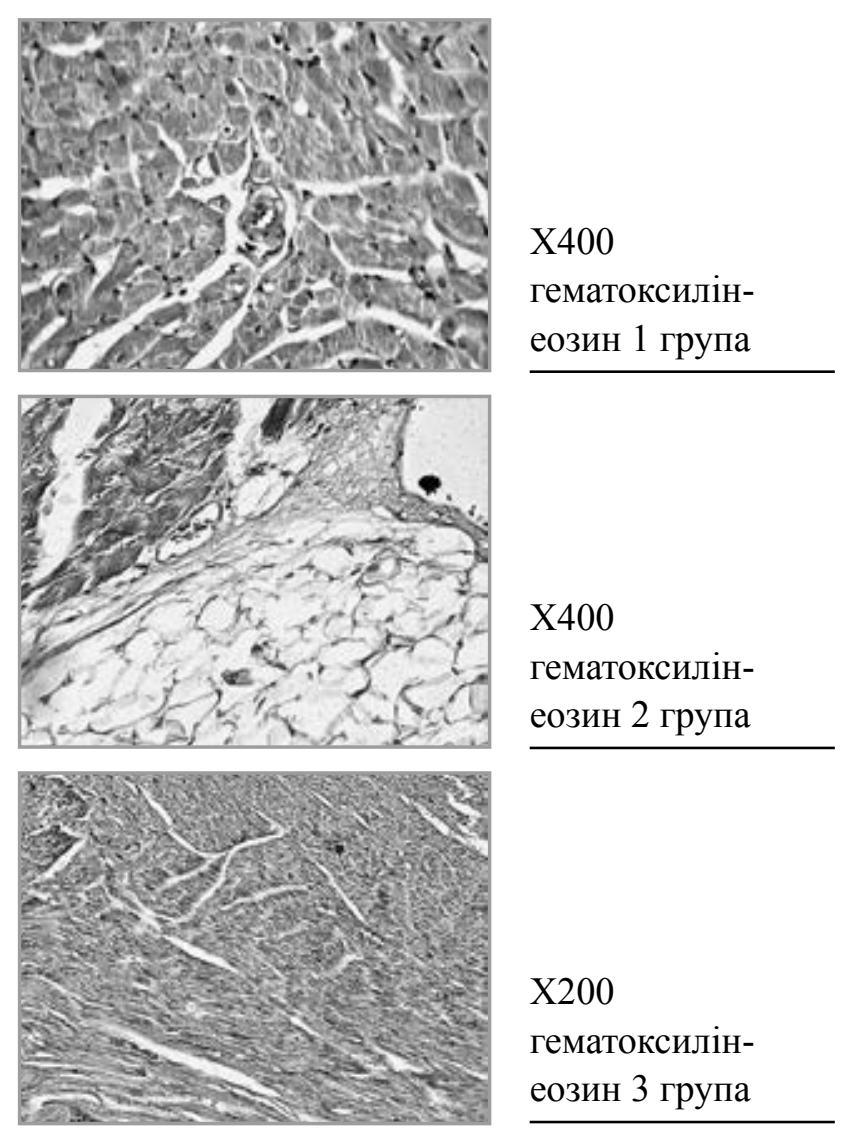

X200

гематоксилінеозин 3 група

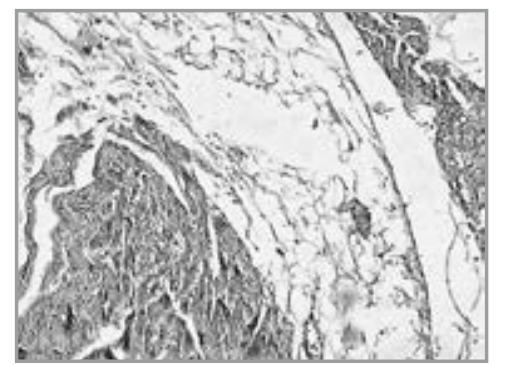

$\mathrm{X} 400$

гематоксилінеозин 4 група

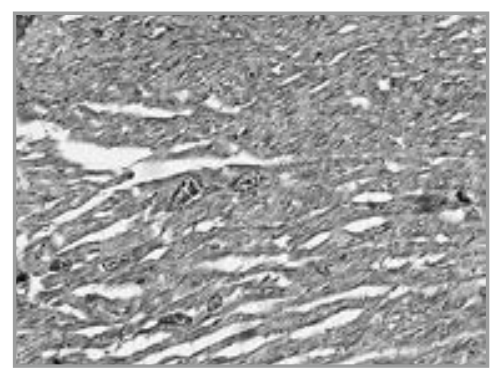

X200

гематоксилінеозин 5 група

Puc.3.

Дослідження мікропрепаратів міокарду відповідно до експериментальної групи

розростання жирової тканини. У піддослідних тварин 3 групи була виявлена втрата просмугованості кардіоміофібрил, вогнищевий набряк, стоншення волокон. Значні крововиливи, утворення перевазатів. У тканинівиражена дистрофія, розростання жирової тканини. У зразках 4 групи щурів - масивне накопичення жирової тканини. Значна дефрагментація кардіоміофібрил, втрата просмугованості тканини. У мікропрепаратах 5 групи відмічається значна дефрагментація тканини 3 вогнищевим нерівномірним стоншенням та потовщенням кардіоміофібрил. Переповнення судин, точкові крововиливи у тканину міокарду, її набряк, утворення перевазатів (рис.3).

Обговорення. Зважаючи на те, що результати експериментального лікування ідентичні 3 результатами дослідження морфологічних змін при розвитку ЦД 2 типу, можна стверджувати, що експериментальне лікування не дало очікуваних результатів та не діє.

Насправді солі гумінових кислот мають дуже складну структуру, що складаються з окремих фрагментів, що повторюються, зв'язаних між собою (рис 4). Вивчено, що гумінові кислоти складаються з 2-15 фрагментів, який має загальну формулу $\mathrm{C}_{305} \mathrm{H}_{299} \mathrm{~N}_{160134} \mathrm{~S}$. Уся молекула згорнута у клубок - агрегант, розмір якого 15 ангстем (1,5 нм або 15 мкм). Зважаючи на те, що гепатоцит має середній діаметр 13-30 мкм, агрегант є вкрай великим для потрапляння в клітину (Попов, 2004).

Висновок: Гумінові кислоти та солі не проникають до клітини через клітинну стінку, в живому організмі зв'язані з металами та неактивні. Зміни, що відбуваються в тканинах печінки, нирок та міокарду під час моделювання експериментального дексаметазонового цукрового діабету і результати отримані після експерементального лікування солями гумінових кислот ідентичні. Тому, використовувати солі гумінових кислот для терапії цукрового діабету 2 типу недоцільно.

Внесок кожного 3 співавторів: Ковальчук О.І. - моделювання цукрового діабету 2 типу, виконання експерименту; Педоренко К.А. - виконання морфологічного дослідження; Ковальчук С.Д. - аналіз хімічних даних дослідження.

Конфлікт інтересів. Дана публікація не викликає будь-якого конфлікту між авторами, не була і не буде предметом комерційної зацікавленості чи винагороди в жодній формі.

Фінансування. Дане дослідження не отримало зовнішнього фінансування. 


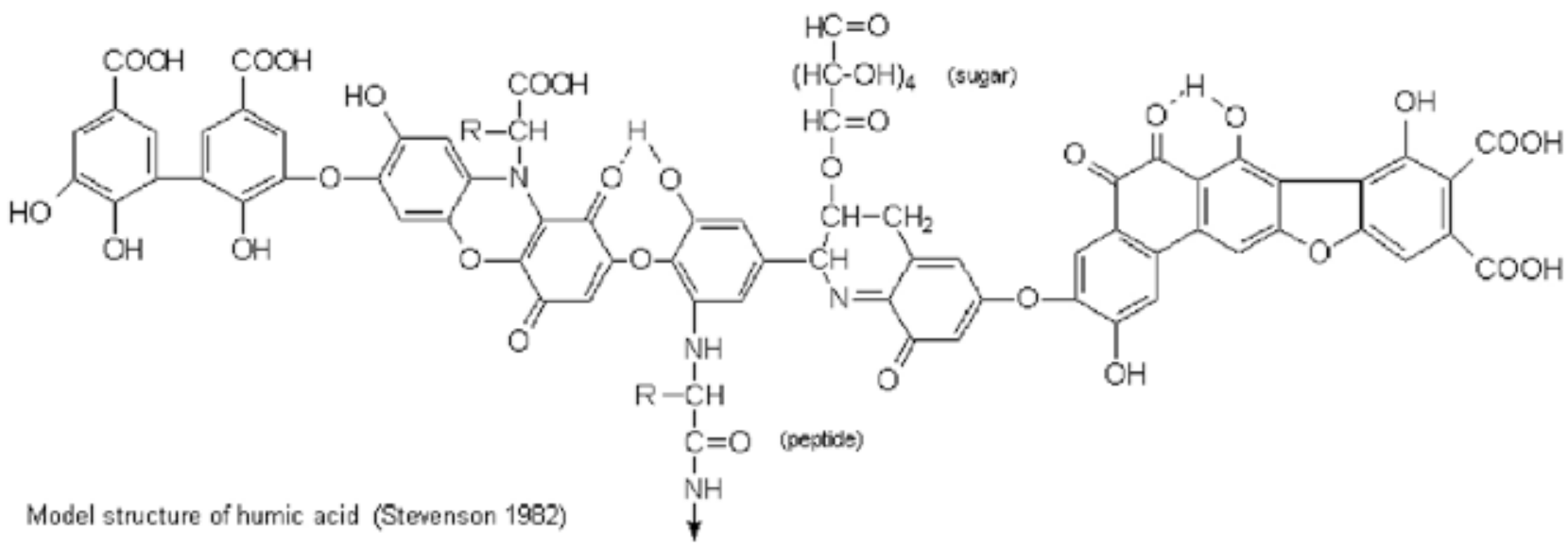

Рис 4. Модель структури фрагменту гумінової кислоти Стівенсона, 1982 рік

\section{ЛITEPATУPA.}

Aeschbacher, M., Sander, M., \& Schwarzenbach, R. P. (2010). Novel electrochemical approach to assess the redox properties of humic substances. Environmental science \& technology, 44(1), 87-93.

Organization.(2020).Diabets. From: https://www.who.int/news-room/fact-sheets/detail/diabetes.

Roglic, G. (2016). WHO Global report on diabetes: A summary. International Journal of Noncommunicable Diseases, $1(1), 3$.

van Rensburg, C. E. J., \& Naude, P. J. (2009). Potassium humate inhibits complement activation and the production of inflammatory cytokines in vitro. Inflammation, 32(4), 270-276.

Аввакумова, Н. П., Герчиков, А. Я., Хайруллина, В. Р., \& Жданова, А. В. (2011). Антиоксидантные свойства гуминовых веществ пелоидов. Химико-фармацевтический журнал, 45(3), 50-51.

Левинский, Б. В. (2000). Все о гуматах. Иркутск: Корф-Полиграф.,71.

Попов, А. И. (2004). Гуминовые вещества: свойства, строение, образование., 248. 


\section{МОРФОЛОГИЧЕСКИЕ ИЗМЕНЕНИЯ ПРИ ЭКСПЕРИМЕНТАЛЬНОМ ЛЕЧЕНИИ САХАРНОГО ДИАБЕТА 2 ТИПА СОЛЯМИ ГУМИНОВЫХ КИСЛОТ.}

\author{
Ковальчук Елена ${ }^{1}$, Педоренко \\ Екатерина $^{2}$, Ковальчук Светлана ${ }^{3}$ \\ ${ }^{1}$ Студент медицинского факультета №1, \\ ВНМУ им. Н.И. Пирогова \\ ${ }^{2}$ Врач-патологоанатом, КНП «ВОПАБ \\ ВОР» г. Винницы \\ ${ }^{3}$ Учитель химии, учитель методист, лицей \\ №25 г. Житомира
}

Аннотация. Заболеваемость сахарным диабетом неуклонно растет приобретая характер настоящей эпидемии и становится вызовом не только для медицины, но и общества в целом. Несмотря на то, что около $90 \%$ всех больных приходится на больных с сахарным диабетом 2 типа. Приоритетным направлением среди исследователей является поиск новых методов лечения сахарного диабета 2 типа. Существует ряд статей о лечении сахарного диабета 2 типа солями гуминовых кислот. Данная статья освещает проведенное экспериментальное исследование лечебных свойств солей гуматов на крысах. Полученные данные в ходе исследования и после исследования морфологических изменений органов-мишеней (печень, почки, миокард) свидетельствуют о недостаточной как протекторное так и терапевтическое действие солей гуминовых кислот.

Ключевые слова: гумат, гумат натрия, морфологическое исследование, протекторное действие гуматов, соли гуминовых кислот, сахарный диабет 2 типа.

\section{MORPHOLOGICAL CHANGES IN THE EXPERIMENTAL TREATMENT OF TYPE 2 DIABETES WITH SALTS OF HUMIC ACID.}

\section{Kovalchuk Olena', Pedorenko Kateryna ${ }^{2}$, Kovalchuk Svitlana ${ }^{3}$}

${ }^{1}$ Student of the medical faculty №1, National Pirogov Memorial Medical University, Vinnytsia

2 Pathologist, CE «VRPAB VRC», Vinnytsia

${ }^{3}$ Chemistry teacher, teacher methodist, lyceum №25, Zhytomyr

Abstract. The incidence of diabetes is growing steadily, becoming a real epidemic and becoming a great problem not only for medicine but also for society as a whole. Due to the fact that about $90 \%$ of all patients are patients with type 2 diabetes. The priority among researchers is to find new treatments for type 2 diabetes. There are a number of articles on the treatment of type 2 diabetes with salts of humic acid. This article highlights the experimental study of the therapeutic properties salts of humate in rats. The data obtained during the study and after the study of morphological changes of target organs (liver, myocard, kidneys) indicate insufficient both protective and therapeutic action salts of humic acid.

Key words: humate, sodium humate, morphological study, protective action of humates, salts of humic acid, type 2 diabetes mellitus. 